УДК 94(477) “653/654”(09)

\title{
МІЖ НОРМАНІЗМОМ ТА АНТИНОРМАНІЗМОМ: ДИСКУСІЇ ПРО ПОХОДЖЕННЯ РУСИ У СВІТЛІ ПИСЕМНИХ ДЖЕРЕЛ
}

\author{
Ольга ЩОДРА \\ Львівський національний університет імені Івана Франка \\ кафедра давньої історії України та архівознавства \\ вул. Університетська 1, Львів, 79000, Україна \\ e-mail: olgashchodra@gmail.com
}

\begin{abstract}
Сучасна полеміка навколо проблеми походження Руси має давню традицію. У ХУІІІ ст. разом із утвердженням російської імперії з дискусії про заснування та початкову історію Руської держави розпочалася російська офіційна історіографія. У іiі становленні та у формуванні норманізму як провідного напряму досліджень з історії Русі важливу роль відіграли німецькі вчені Готліб Байер, Готфрід Міллер та Август Шльоцер, які розвинули ідеї про вирішальну участь скандинавів в її заснуванні, започатковані шведськими істориками ХУІІ ст. У поширені норманізму в європейській історіографії значну роль відіграли французький просвітитель Шарль Луї Монтеск'є та німецькі філософи Йоган Фіхте і особливо Георг Гегель. Одночасно 3 норманською теорією походження Русі розвивався антинорманський напрям в історіографії, початок якому поклала дискусія Михайла Ломоносова з Г. Міллером на засіданнях Імператорської Академії Наук. До початку XX ст. представники обох напрямів історіографії послуговувалися в основному писемними джерелами, вичерпавши їх інформаційний потенціял для дослідження даної теми. У працях М. Ломоносова, Густава Еверса, Сергія Гедеонова, Дмитра Іловайського більшість аргументів класичної норманської теорії, зокрема про шведське походження засновника руської династії Рюрика і назви “русь”, були спростовані, однак їх і сьогодні використовують російські історики з метою довести північне походження Руси (так званого Ладозького руського каганату).

Ключові слова: Русь, теорія, норманісти, історіографія, походження, Росія.
\end{abstract}

У сучасних східноевропейських історіографіях, і насамперед російській, 3 новою силою розгорнулися дискусії про походження Руси. Однією із причин загострення полеміки стала боротьба за їі історичну спадщину, яка розпочалася після того коли втратила свою актуальність радянська концепція “колиски східнослов'янських народів”. Як зауважив російський дослідник східноевропейського середньовіччя Аполлон Кузьмін, боротьба між спадкоємцями розгортається (в історіографії) за гідну історичну спадщину. Саме такою була державна і культурна спадщина Руси, що уже на початку свого формування - у 814 р. - зрівнялася територією з Візантійською імперією та імперією Каролінгів ${ }^{1}$, а в період свого розквіту, в часи правління Володимира Великого, перетворилася у найбільшу европейську державу. У той час, коли

\footnotetext{
${ }^{1}$ Борис Рибаков. Кивская Русь и русские княжества XII-XIII вв. (Москва: Наука, 2013), 48.
} 
ISSN 2078-6077. Наукові зошити історичного факультету Львівського університету. 2018-2019. Випуск 19-20. Proceedings of History Faculty of Lviv University. 2018-2019. Issue 19-20.

після падіння Риму Західна Европа поволі виходила з часів культурного занепаду, так званих Темних століть, Руська держава разом із прийняттям християнства долучилася до візантійської цивілізації та її джерел - античної культурної спадщини. Їх симбіоз із слов' янською язичницькою традицією породив культуру Старокиївської держави з її величними храмами, чудовими фресками та мозаїками, шедеврами рукописної книги, школами та книгозбірнями, філософами та літописцями. Німецький хроніст першої половини ХІ ст. Тітмар Мерзебурзький описував столицю Русі як велике місто, значний торговельний центр, у якому сотні церков і “незліченна кількість” населення ${ }^{2}$. У XII-XIII ст. за чисельністю людности-приблизно 50 тисяч чоловік - Київ був одним із найбільших европейських міст ${ }^{3}$. Так само, як цивілізаційний вплив Візантії не припинився із завершенням ії політичної історії, породивши феномен “Візантії після Візантії”, культурний вплив Руси століттями позначався на історичному розвитку Східної Европи і відчутний до сьогодні на ментальному та культурному рівні ії народів.

Свого часу російська історіографія, що проходила етап свого становлення у XVIII ст. разом із формуванням імперії Романових, не вагаючись привласнила історію Руси і долучила ії до загальної схеми російської історії. Це надавало їй бажаної европейськості та історичної тяглости, тоді як Україна втрачала не лише залишки державної автономії, а й власну історію. Критикуючи “звичайну історичну схему" Росії, Михайло Грушевський вказував, що вона позбавляла росіян можливости зрозуміти справжні витоки їхньої історії. “Історія великоруська 3 українсько-руським (київським) початком, пришитим до неї - се тільки калікувата, неприродна комбінація...". Українська ж історія, на думку вченого, без історії Київської Руси “зістається не тільки без початку, а і в виді якихось кавалків, не пов'язаних між собою органічно, розділених прогалинами”.

Наприкінці XX ст. історія повторилася. Після нетривалого періоду роздумів і вагань ${ }^{6}$ російські історики знову повернулися до імперської історіографічної спадщини, до “звичайної історичної схемио Миколи Карамзіна, у якій Руська держава $€$ невід'ємною частиною національної і державної історії Росії. “Звичайна схема" покладена в основу історичної навчальної літератури в сучасній Росії і стала частиною державної політики історичної пам'яті, а Київська Русь, за чисельністю присвячених їй наукових публікацій, входить до числа пріоритетних та найактуальніших тем російської історичної науки. Стислий екскурс в історію становлення та розвитку історіографії Руси допоможе краще зрозуміти сучасну

\footnotetext{
${ }^{2}$ Титмар Мерзебургский. Хроники (1012-1018). Древняя Русь в свете зарубежных источников. (Москва: Русский Фонд Содействия Образованию и Науке, 2010). Т. 4, 82.

${ }^{3}$ Гліб Івакін. Оповіді про стародавній Київ. (Київ: Радянська школа, 1982), 78.

${ }^{4}$ Грушевський М. Звичайна схема “русской” історії й справа раціонального укладу історії східного слов'янства. Український історичний журнал 5. (2014), 207.

${ }^{5}$ Там само, 205.

${ }^{6}$ Див.: Борис Земцов Откуда есть пошла... росийская цивилизация. Общественные науки и современность. (Москва, 1994), 52.
} 
полеміку навколо проблеми походження руської середньовічної держави, іiі науковий та політичний аспекти.

Дискусії про походження Руси розпочалися в російській історіографії одночасно з ії становленням - у ХУІІІ ст. 3 них власне і починалася російська історична наука ${ }^{7}$. Попри істотні відмінності в поглядах на проблему, які поділили істориків на два табори - норманістів та антинорманістів - усі вони були солідарні щодо того, що Русь $є$ невід’ємною частиною історії Росії, наріжним каменем у фундаменті державної історії Російської імперії. Від самого початку студії над проблемами утворення Руси мали політичний характер, оскільки саме долучення іiі історії до російської було політично вмотивоване. Привласнюючи українську історію, російська офіційна історіографія також ставила за мету легалізувати та ідеологічно обгрунтувати інкорпорацію українських земель до складу імперії, що неухильно проводила російська влада впродовж XVIII ст.

Політична вмотивованість, зокрема ідеї про особливу роль германських народів в історії Европи, спочатку готів (готицизм), а потім норманів (норманізм), впливала також на студії німецьких вчених над руською історією. Запрошені до праці в Імператорській Академії Наук, вони зробили норманізм засадничою ідеєю походження Руси, згідно з якою заслуга заснувати правлячу династію i державу належала скандинавам. Уперше такі ідеї сформульовала шведська історіографія, що на століття раніше, ніж російська, пройшла етап свого становлення. Він також співпав із формуванням імперської політичної програми Швеції та розгортанням іiї експансії на південно-східному узбережжі Балтики, зокрема в Новгородській землі. Саме тоді, у XVII ст., з метою утримати захоплені в роки Смути Новгородські землі та легітимізувати шведську експансію виникає “скандинавський догмат”, одним із авторів якого був шведський історик Петро Петрей. У праці “Історія про велике князівство Московське” (опублікована у 1614-1615 pр.) він використав сфальшовану шведськими політиками промову новгородських послів, проголошену 28 серпня 1613 р. у Виборзі перед братом шведського короля Густава II герцогом Карлом-Філіпом, у якій нібито стверджувалось, що “новгородці можуть по літописах довести, що у них був великий князь зі Швеції по імени Рюрик". Ця фальшивка стала основою норманської теорії. Для іiі обгрунтування П. Петрей почав тлумачити на скандинавський манер імена руських князів, пояснюючи відмінність у звучанні тим, що руси неправильно вимовляли шведські імена. За його припущенням, літописний Рюрик міг у шведів називатися Ерік, Фрідерік, Готфрід, Зігфрид, Родріг, а його брат Синус - Сиге, Свен, Симон, Трувер - Туре, Трогге 9 . Після

\footnotetext{
${ }^{7}$ Аполлон Кузьмин. Начало Руси: Тайны рождения руського народа. (Москва: Вече, 2003), 8.

${ }^{8}$ Цит. по: Вячеслав Фомин. Варяги и варяжская Русь. К итогам дискуссии по варяжскому вопросу. (Москва: Русская Панорама. 2004), 13.

${ }^{9}$ Пётр Петрей де Ерлезунда, История о Великом княжестве Московском, происхождении великих русских князей, недавних смутах, произведенных там тремя Лжедмитриями и о московских законах, нравах, правлении, вере и обрядах, которую собрал и обнародовал в Лейпциге 1620 г., пер. с нем. Алексея Шемякина (Москва: Университетская типография “Катков и К”, 1867).
} 
ISSN 2078-6077. Наукові зошити історичного факультету Львівського університету. 2018-2019. Випуск 19-20. Proceedings of History Faculty of Lviv University. 2018-2019. Issue 19-20.

Петрея таке етимологічне свавілля стало звиклою практикою норманістів. Цей "метод" досліджень добре змалював один із творців норманської теорії Август Шльоцер: “Слово піднімають на етимологічну дибу і мучать до тих пір, поки воно ніби від болю не видасть з себе стогону або крику такого, якого хоче словотворець”

“Скандинавський догмат”, за влучним висловом одного з сучасних дослідників В'ячеслава Фоміна, “створив віртуальну норманську Русь, якої ніколи не існувало в історії, заслонивши собою Русь справжню""1. Згідно з ним, державотворчі процеси у Східній Европі були спричинені винятково і тільки діяльністю скандинавів. Шведські історики XVI-XVII ст. П. Петрей, Олаф Рудбек, Йоган Магнус, Олаф Далін, та ін. доводили, що варяги і русь - це скандинави, що руську правлячу династію та державу заснували шведи і від імени одного із шведських племен походить ії назва, що первісний центр Руси був не у Середньому Подніпров'ї - у Києві, а на півночі Східної Европи - у Новгороді. Саме шведські історики відкрили всі головні писемні джерела, на яких до XIX ст. базувалися основі аргументи норманської теорії, “саме вони ототожнили варягів з візантійськими “варангами" i “веригами” ісландських саг, слово “варяг” оголосили давньоскандинавським, видали імена руських князів за скандинавські і т. д." ${ }^{2}$. Уявлення про варягів як скандинавів, без надання жодних переконливих аргументів, стало основною віссю, навколо якої вибудовувалася норманська конструкція початкового етапу історії Руси.

Політична заангажованість творців норманської теорії та їх послідовників впливала на підбір та інтерпретацію історичних джерел. Так, “ультрапатріотичний панегірик” Йогана Магнуса “Історія всіх готських і шведських королів”, виданий у Римі в 1554 р., був написаний на основі ісландських саг, міти і легенди яких автор сприйняв абсолютно некритично ${ }^{13}$.

Скандинавський догмат став частиною мітологізації та героїзації епохи вікінгів в европейській історіографії. Сприятливий грунт для нього підготували ідеї готицизму, що набули поширення в Европі в епоху Відродження. Згідно з ними, визначальний вплив германців на европейську історію почався ще 3 епохи Великого переселення народів. Шведські історики, всупереч інформації середньовічних джерел, проголосили Скандинавію батьківщиною готів, хоча ця назва закріпилася за півостровом лише в XV ст., а до того назви "Сканія" (Skania) і "Скандинавія" (Skatinavia) античні та середньовічні автори давали різним островам південних та північних морів ${ }^{14}$. Який із північних островів називав Скандзою перший історик готів Йордан можна лише гадати ${ }^{15}$.

${ }^{10}$ Август-Людвиг Шлецер. Нестор. Ч.ІІ. (СПб.: Императорская типография, 1816): 114-115.

${ }^{11}$ Пётр Петрей де Ерлезунда, История о Великом княжестве Московском..., 123.

${ }^{12}$ Вячеслав Фомин. Начальная история Руси.(Москва: Русская панорама, 2008), 10.

${ }^{13}$ Див.: История Швеции. (Москва: Наука, 1974), 8.

${ }_{14}$ Див.: Лидия Грот. Призвание варягов.Норманская лжетеория и правда о князе Рюрике. (Москва: Алгоритм, 2012) ; Svennung J. Zur Geschichte des goticismus. (Stokholm: Almgvist och Wiksell, 1967).

${ }^{15}$ Шарль Луи Монтескье. Избранные произведения о духе законов. (Москва: Госполитиздат, 1955), 252. 
Немалу роль у героїзації та міфологізації епохи вікінгів відіграли французькі просвітителі, зокрема Шарль Луї Монтеск’є, який у праці “Про дух законів” захоплено писав про "велику перевагу, яка ставить народи, які населяють цю країну (Скандинавію) вище всіх народів у світі саме тому, що вони були джерелом свободи в Европі, ... які виступають із своєї країни для того, щоб знищити тиранів і рабів..."16 Така характеристика ще більше надихнула шведських істориків, які зображували ватаги норманів не морськими піратами і грабіжниками, якими вони були насправді, а державотворцями і цивілізаторами Европи. Так, придворний королівський історик О. Далін в багатотомній “Історії Шведського королівства" писав, що Руська держава була під управою Варязького або Шведського королівства. Для більшої правдоподібности цього твердження він, як і його попередник П. Петрей, почав тлумачити імена руських князів як скандинавські: Олега - Олаф, Ігор-Інгер, Володимир-Вольдемар, Ярослав-Гаральд. Їх різне звучання він так само пояснював тим, що руси неправильно вимовляли та перекручували скандинавські імена. За допомогою таких “методів” досліджень шведські історики переносили події руської історії у шведську ісаму Русь почали вважати іiі частиною. Так, у 1774 р. вийшла праця шведського історика Йогана Тунманна, у якій він також стверджував, що Русь заснували нормани (шведи) ${ }^{17}$.

Захоплені імперським мітом про Велику Швецію, який самі і створили, шведські історики спробували привласнити не лише руську, а й античну історію та намагалися довести скандинавське походження гіпербореїв і античних мітів. Одним із найодіозніших апологетів “давньої слави” Швеції вважається О. Рудбек, який у своій трихтомовій праці “Атлантида” ототожнив давню Швецію 3 Атлантидою Платона і писав, що гіпербореї - це шведи, що шведський бог Один став грецьким богом Аполоном і т. п. Він відводив Швеції головну роль не лише в руській, а й в давньогрецькій історії ${ }^{18}$. Використовуючи вже апробований попередниками метод довільного тлумачення грецьких і руських імен як скандинавських він, за висловом сучасного шведського історика Йогана Свеннунга, довів цю сумнівну практику словоутворення до вершин недолугости ${ }^{19}$.

Аргументи, які наводили шведські автори для обгрунтування норманської теорії, були настільки неправдоподібними та одіозними, що їх не сприйняли навіть класики норманізму - німецькі історики ХУІІІ ст. Так, Герхард Міллер іронізував над тим, як Рудбек “вмів відразу зробити з Ладоги “Ладогу”, після чого “Аллдейгабор"20 (цю сумнівну схему продовжують використовувати сучасні

${ }^{16}$ Олаф Далин, История шведського государства. Ч.1. Кн.1 (СПб.: Императорская типография, 1805), 71-72, 123-124, 385.

${ }^{17}$ Thunmann J., Untersuchungen über die Geschichte der ostlichen europäischen Völker. Teil 1. (Leipzig: 1774), 371-372.

18 Докладніше див.: Вячеслав Фомин, Начальная история Руси (Москва: Русская панорама, 2008),19-20; Грот. Призвание варягов: норманская лжетеория и правда о князе Рюрике.

${ }^{19}$ Svennung, Zur Geschichte des Goticismus, 44

${ }^{20}$ Готфрид Миллер, О народах издревле в России обитавших (СПб.: Типография Императорской Академии наук, 1788), 104. 
ISSN 2078-6077. Наукові зошити історичного факультету Львівського університету. 2018-2019. Випуск 19-20. Proceedings of History Faculty of Lviv University. 2018-2019. Issue 19-20.

норманісти). Пізніше, в середині XIX ст., російський історик Сергій Соловйов говорив, що словоутворення Рудбека, яке базувалося лише на зовнішній подібності звуків викликало “відразу і сміх вчених"21. Попри те, твори шведських істориків і особливо “Історія" О. Даліна відіграли величезну роль у поширенні норманізму в західноевропейській науці, а праця П. Петрея в XVII ст. сприймалася европейськими вченими як авторитетне видання з історії Східної Европи.

Політичний контекст формування норманської теорії походження Руси в російській історіографії XVIII ст. наголошує А. Кузьмін. Вчений вважає, що немалу роль у іiі розвитку відіграла та обставина, що на той час німецькі спадкоємці Лівонського ордену, землі якого після Лівонської війни були приєднані до Московії, стали привілейованою верствою Московської держави і багато німецьких графів та баронів служило при імператорському дворі. Вони суттєво впливали на політику російських монархів, династично пов'язаних з німецькими князями та були надійною опорою імперії ${ }^{22}$. Тому саме запрошеним німецьким історикам Готлібові Байєру, Герхардові Міллеру і Августу Шльоцеру було доручено написати історію Російської імперії. Піддавши гострій критиці окремі твердження шведських попередників, як бездоказові і надумані, німецькі історики в цілому сприйняли і розвинули їх ідеї. Як вказує А. Кузьмин, “формальна “німецька вченість” замість скільки-небудь обгрунтованих теорій брала за основу наївний германоцентризм, крізь призму якого розглядала всі явища історії слов'ян і руси" 23 . Сповідуючи пангерманізм, німецькі історики у своїх студіях змальовували германців споконвічними культуртрегерами у Східній Европі, без участі яких тут не відбувався жодний поступ, зокрема й утворення держав. Вони сформулювали основні аргументи класичної норманської теорії утворення Руси - теорії норманського завоювання ${ }^{24}$. Найбільший вклад у ії обгрунтування зробив Г. Байєр - ультранорманіст, за визначенням В'ячеслава Мошина, автора одного 3 найгрунтовніших оглядів історії норманізму ${ }^{25}$. Він ввів в обіг нове джерело з історії Руси - франкську Бертинську хронічку - та навів усі основні аргументи норманської теорії, якими послуговуються і сучасні норманісти, а саме: Русь постала внаслідок норманського завоювання місцевих племен, яке, на думку Г. Баєра, літописець дещо пом'якшив, змалювавши як добровільне прикликання норманських конунгів; шведський конунг Рюрик був засновником

${ }^{21}$ Сергей Соловйов, Август-Людвиг Шлецер. Собрание сочиений С. М. Соловйова (СПб.: Издание Товарищества Общественной Пользы, 1901),1547.

${ }_{22}^{2}$ Аполлон Кузьмин. Начало Руси: Тайны рождения руського народа..., 4.

${ }^{23}$ Там само, 36.

${ }^{24}$ Докладніше про це.: Фомин, Варяги и варяжская Русь, 16-26.

${ }_{25}$ Владимир Мошин, Варяго-русский вопрос. Варяго-русский вопрос в историографии, ред. Вячеслав Фомин (Москва: Русская панорама, 2010), Историческая библиотека, доступ отримано 31 грудня 2016, http://historylib.org/historybooks/Fomin_Varyago-Russkiy-vopros-vistoriografii/2. 
руської династії; назва Руської держави походить від назви одного із шведських племен, літописні варяги, як і руси, - це скандинави. Він також скористався методом Рудбека і намагався довести скандинавське походження імен руських князів, перекручуючи їх на скандинавський манер. Август Шльоцер, оцінюючи підготовленість Г. Байера до студій над руською історією писав, що Байєр не знав російської (і жодної іншої слов'янської - . Щ.) мови і завжди залежав від не надто вправних перекладачів літописів, він занадто довіряв ісландським сагам - “ісландським казкам" і наробив важливих та численних помилок. "У нього немає чому навчитися в російській історіі”'26.

Особливо гостро А. Шльоцер критикував сумнівні етимологічні вправи своїх колег, вказуючи, що “подібність в іменах, пристрасть до словоутворення - дві найплодючіші матері здогадок, систем і дурниць”. Вчений задавався питанням: "Невже після всієї цієї руїни, яку вчинив рудбекіянізм, вони (вчені XVIII ст. О.Щ.) не втомилися творити з етимологій історію, а на простому, можливо випадковому збігові слів вибудовувати цілі теорії?”27.

На думку В. Фоміна, однією з причин поширення норманізму в Росії та його сучасної популярности $є$ намагання російських вчених конструювати східноевропейську історію за схемами західноевропейської історичної та філософської науки. ${ }^{28}$ Свого часу історик Іван Забєлін писав, що в глибині національної свідомости російських освічених людей лежить “невідпорне рішення", що “все добре російське неминуче запозичене де-небудь в чужоземців" 29.

Норманську версію утворення Руси Г. Байєр протиставив іншій, що домінувала в тогочасній европейській історіографії. Згідно з нею, варяги були не скандинавами, а вихідцями зі слов'янської області Вагрії, розташованої на південному узбережжі Балтики і населеної слов'янським племенем вандалів*.

У XVI ст. цієї версії дотримувався добре інформований посол імперії Габсбургів Сигізмунд Герберштайн, який побував з посольською місією в Данії, (у складі якої у той час перебувала слов'янська Вагрія), Польщі, тобто, добре

${ }^{26}$ Константин Бестужев-Рюмин, Биографии и характеристики (летописиьы России)(Москва: ВEK, 1997), 170.

${ }^{27}$ Август-Людвиг Шлецер. Нестор. Ч.ІІ. (СПб.: Императорская типография, 1816): 115.

${ }^{28}$ Вячеслав Фомин. Начальная история Руси.(Москва: Русская панорама, 2008), 27.

${ }^{29}$ Иван Забелин, История русской жизни с дрвнейших времен. Ч. І (Москва: Типография Грачева, 1876), 65.

* За повідомленнями европейських середньовічних авторів, вандали, як і герули, були слов'янським племенем, яке деякі дослідники ототожнюють 3 венедами. Перші королі вандалів, які правили у IV ст., мали слов'янські імена Радегаст, Годегуслус (а королі герулів - Мечислав, Віслав). Оскільки їх нащадки наприкінці IV ст. мали тевтонські імена (Готерік, Генсерік), що 3'явилися внаслідок укладення династичних шлюбів з сусідніми германцями, то в історіографії, зокрема німецькій, усталилася думка про вандалів як одне з германських племен. Див.: Владислав Меркулов, Откуда родом варяжские гости? Генеалогическая реконструкиия по немеиким источникам (Москва. 2005), доступ отримано 10 листопада 2018 p. https://old- earthnarodru/lib/ slav/balt/merkulov earthnarodru/lib/slav/balt/merkulov-varangian-guests.pdf 
ISSN 2078-6077. Наукові зошити історичного факультету Львівського університету. 2018-2019. Випуск 19-20. Proceedings of History Faculty of Lviv University. 2018-2019. Issue 19-20.

знав південнобалтійський регіон. Він вказував, що Вагрія колись була славним містом і областю вандалів, які були могутні і мали мову, звичаї і релігію русів (тобто, слов'ян - О. Щ.). Від Вагрії і вагрів (варягів) Балтійське море отримало назву Варязького ${ }^{30}$.

На думку С. Герберштайна, мабуть таки руси прикликали собі князів (Рюрика з братами - O. Щ.) від вагрів або варягів, ніж запропонували владу чужоземцям 3 чужою релігією, звичаями і мовою ${ }^{31}$. Такої ж думки був автор популярного “Загального історичного словника", який вийшов у 1619 р. Клод Дюре. Однак поступово, після виходу праць шведських і німецьких істориків, домінантною в европейській історіографії стала версія скандинавського походження варягів.

У середині XVIII ст. одночасно з норманською теорією та у гострій полеміці з іï авторами формується антинорманський напрям в історіографії, засновником якого вважається Михайло Ломоносов. Сучасні норманісти часто звинувачують його в тому, що він нібито вів полеміку не стільки з наукових як із патріотичних міркувань. Насправді його аргументи, зокрема зауваження до дисертації Г. Міллера “Походження імени і народу руського", попри емоційний характер дискусії, мали цілком науковий характер. Так, вчений вважав неможливим, щоб “два народи, слов'яни і варяги, покинули свої колишні імена і назвалися новим, яке пішло не від них, а було взято від чухонців (від фінського “Ruotsi”. О. Щ.)”. Він вказував, що наведений німецьким істориком "приклад англійців і французів служить не в підтвердження цієї вигадки, а в заперечення, тому, що там переможені від переможців ім'я отримали. А тут ні переможці від переможених, ні переможені від переможців, але всі від чухонців!"32. Як аргумент проти норманської версії походження Руси він наводив також той факт, що в руській мові практично не було германізмів, що $\epsilon$ немислимим, якщо б русь і варяги були панівним германським етносом ${ }^{33}$. Задаючи Г. Міллерові питання, чи знайшов він у скандинавських джерелах хоч якісь згадки про Рюрика та його рід, М. Ломоносов наголошував, що “якщо б він (Рюрик - О. Щ.) був скандинавом, то норманські письменники звісно б не пропустили такого знатного випадку в історіях для чести свого народу..." ${ }^{34}$. Відсутність згадок про Рюрика у скандинавських джерелах вчений вважав переконливим доказом, що такого шведського конунга не існувало ні у шведській, ні в руській історії. Аргументи М. Ломоносова, спрямовані проти сумнівних доказів норманістів, підтримали i розвинули Густав Еверс, Степан Гедеонов, Дмитро Іловайський, а з окремими (про відсутність слідів скандинавських мовних впливів, про сумнівність фінського

30 Записки о Московии Барона Герберштейна, Пер. с нем. И. Анонимова (С.-Петербург: Типография Безобразова и комп. 1866), 10.

${ }^{31}$ Там само.

32 Михаил Ломоносов, Полное собрание сочинений (Москва-Ленинград: Издательство АН CCCP, 1952). Т. 6, 81-82.

${ }^{33}$ Там само,35.

${ }^{34}$ Там само, 77, 216. 
походження назви “Русь”) погоджувались навіть норманісти, зокрема А. Шльоцер, Костянтин Бестужев-Рюмін ${ }^{35}$.

Іншого представника норманізму - Г. Байера, російський історик критикував за показну формальну вченість і за абсолютно довільне (в дусі О. Рудбека) перекручення руських імен на скандинавський лад. М. Ломоносов вказував, що “старається Байер не стільки про дослідження правди, скільки про те, щоб показати, що він знає багато мов і читав багато книжок" 36 . Наукову неспроможність Байерового методу трактування імен варязьких князів як скандинавських також переконливо доводив Василь Татіщев, який вказував, що німецький дослідник, порівнюючи імена, шукає лише подібности із скандинавськими без етимологізації самих імен ${ }^{37}$. Аргументи В. Татіщева i сьогодні зберігають наукову значимість та актуальність. Сучасні дослідники теж відзначають сумнівне скандинавське трактування імен Олег, Ольга, Ігор лише на основі їх подібности до скандинавських Хельгу, Хельга, Інгвар. Так, В. Фомін на доказ того, що ці імена не були пов'язані зі скандинавами наводить той факт, що ім'я Ольга було поширене в середньовічній Чехії, на території якої практично не виявлено слідів перебування норманів ${ }^{38}$. На думку дослідниці Лідії Грот, у Швеції імена Хельг, Хельга, що означають “святий”, “свята”, мали б 3'явитися тільки після прийняття християнства, тобто не раніше другої половини X ст., тоді як у літописі імена Олег і Ольга* згадуються вже у IX-першій половині $\mathrm{X}$ ст. Слушним є також іiі зауваження, що прізвисько князя Олега "Віщий” свідчить про те, що він був ведуном, тобто язичником, тим, хто здобував знання 3 допомогою волхвів та ворожіння, і воно є антагоністом християнського розуміння святости та поняття “святий”з 9 . Зв'язок слова "helge” (“святий”) та похідних від нього імен з поширенням християнства підтвердили дослідження ісландських саг. На їх основі Л. Грот дійшла до висновку, що імя “Helge" вперше згадується у зводі саг XIII ст. і пов'язане з поширенням християнства у Швеції в XII ст., а тому не має жодного зв'язку з руським іменем Олег ${ }^{40}$. Свого часу історик Іван Івакін також з'ясував, що ім'я Ігор не має жодного стосунку до скандинавського імені Інгвар. Ім'я Ігор було відоме літописцям, починаючи від $\mathrm{X}$ ст., а ім'я Інгвар з'являється на сторінках літописів лише наприкінці XII - на

${ }^{35}$ Шлецер, Нестор. Ч. II. 172; Костянтин Бестужев-Рюмин. Русская история (СПб.: Издательство Д. Е. Кожанчикова, 1872). Т. 1, 93.

${ }^{36}$ Михайло Ломоносов. Полное собрание сочинений. Т. 6, 30-31.

${ }^{37}$ Василий Татищев. История Российская с самих древнейших времен. Т.1. (Москва-Ленинград: Наука, 1962): 205, 308-309.

${ }^{38}$ Вячеслав Фомин. Начальная история Руси.(Москва: Русская панорама, 2008), 241.

*На думку деяких дослідників, руська княгиня Ольга згадується у сагах під іменем Аллогія.

39 Лидия Грот, Мифолоические и реальные шведы на севере России: взгляд из шведской истории. Шведы и Русский Север: историко-культурные связи. Материаль международного симпозиума к 210 летию Александра Лаврентиевича Витберга. (Изд-во Киров, 1997), 153-158.

${ }^{40}$ Там само. 
ISSN 2078-6077. Наукові зошити історичного факультету Львівського університету. 2018-2019. Випуск 19-20. Proceedings of History Faculty of Lviv University. 2018-2019. Issue 19-20.

початку XIII ст. Ці імена на Руси розрізняли. Як зауважує I. Івакін, “якщо б вони були одинакові, навіщо було б князеві (рязанському - О. Щ.) Ігореві Глібовичу (княжив від 1195 р.), давати своєму сину ім'я не Ігор, а Інгвар. Але син його називався не Ігор Ігоревич (що було б логічно, якщо б імена були тотожні - О. Щ.), а Інгвар Ігоревич" ${ }^{41}$. Дослідник вказує, що в середньовіччі у скандинавів, слов'ян та інших народів існувала традиція, згідно з якою первістку під час хрещення давали ім'я дідуся або бабусі по батьківській лінії, а другим за народженням дітям - імена бабусь і дідусів по материнській лінії ${ }^{42}$. Тому після одруження руських князів на чужоземках в їхніх дітей з'являлися скандинавські й інші чужоземні імена: у князя Володимира Святославовича від дружини чехині були сини з чеськими іменами Станіслав і Вишеслав, у Володимира Мономаха від дружини англійки - син Мстислав-Гаральд, діти чернігівського князя Ростислава Михайловича від дружини-угорки називалися Бела, Міча і Кунгута, серед імен нащадків галицько-волинського князя Романа Мстиславовича після його одруження на грекині з'явилися імена популярні у Візантії - Данило, Лев, Іраклій, Софія. Так само діти скандинавських правителів, дружини яких були слов'янками, мали слов'янські імена Яромир, Святополк, Борислав, Воіслава та ін.

Представники правлячих династій міцно трималися за свої родові імена. Наприклад, поморські князі, які онімечилися в XIII ст., ще майже чотириста років продовжували використовувати свої слов'янські імена аж до вимирання роду (до 1637 р.) Так само, попри асиміляцію 3 німцями, аж до вимирання княжого роду продовжували носити свої династичні слов'янські імена руяни (слов' яни, які в середньовіччі населяли острів Рюген в Балтійському морі- $О$. Щ. $)^{43} .3$ огляду на це, з позицій норманізму не можна пояснити той факт, що серед імен руських князів майже відсутні скандинавські імена. Навіть якщо сприйняти аргумент про повну і швидку асиміляцію скандинавів, то відповідно до встановленого дослідниками правила, усі руські князі по чоловічій лінії мали б мати скандинавські імена. Як вказує сучасний дослідник скандинавської антропонімії Аркадій Молчанов, “успадкування імен своїх предків, причому по чоловічій і жіночій лінії, було для хьовдінгів ніби одною із звиклих форм публічнї репрезентації невід'ємних законних прав, отриманих після народження"44. Упродовж XVIII-XIX ст. полеміка норманістів і антинорманістів базувалася лише на інтерпретаціях писемних, зокрема літописних джерел. Вона грунтовно висвітлена у працях В'ячеслава Мошина, В'ячеслава Фоміна, Аполона Кузьміна,

\footnotetext{
${ }^{41}$ Иван Ивакин. Князь Владимир Мономах и его поучение. Ч. 1. (Москва:Университетская типография. Страстной бульвар, 1901), 54.

${ }^{42}$ Там само, 55.

43 Фомин. Варяги и варяжская Русь, 396.

${ }^{44}$ Аркадий Молчанов. Древнескандинавский антропонимический элемент в династической традиции рода Рюриковичей . Образование Древнерусского государства: спорные вопросы. (Москва: Наука, 1992), 45.
} 
Леоніда Клейна, Ігоря Шаскольського та інших авторів. У ході дискусій був нагромаджений великий матеріял, що, на думку дослідників, дозволяв зробити цілком конкретні висновки, але цьому перешкоджала заполітизованість проблеми та тенденційність більшости ії дослідників, що й сьогодні перешкоджають об'єктивному висвітленню початкової історії Русі ${ }^{45}$. Значний вплив на західноевропейську історичну науку справили праці німецьких філософів Фіхте і Гегеля, які проповідували ідею виняткової ролі германців і зокрема скандинавів в европейській історії. Гегель особливо наголошував на “історичних" та "неісторичних" народах, здатних і нездатних створити державу. До перших він зараховував германців, а до других - слов’ян. У своїй “Філософії історії”, що була курсом лекцій для студентів Берлінського університету, він відзначав, що “у Східній Европі ми знаходимо величезну слов'янську націю, що розташовується на Заході вздовж Ельби до Дунаю... Однак уся ця маса вилучається з нашого огляду тому, що вона до цього часу не виступала як самостійний елемент в ряду виявлення розуму у світі”. Характеризуючи скандинавів як "рицарів у чужих країнах", він вказував, що “частина 3 них скерувалась до Росії і створила там руську державу"46. Ці ідеї, що стали домінантними в европейській i, насамперед, в німецькій історичній школі до середини XX ст., впливали на інтерпретацію джерел та визначали характер досліджень з історії слов'янських народів.

Упродовж XIX-XX ст. ідеї німецьких філософів підтримували норманізм у західноевропейській історіографії, оскільки у східноевропейській він поступово втрачав свої позиції. Так, сумніви свого покоління істориків щодо можливости об'єктивно висвітлити походження Руси з позицій норманської теорії відзначав Василь Ключевський. Він писав: “Ми відчували, що в ній (норманській теорії. O. Щ.) багато нескладного, але не наважилися сказати щось проти неї. Ми іiі зберегли як учні ії творців і не знали, що з нею робити, як викладачі”"47 Грунтовну і аргументовану критику норманської теорії дав М. Грушевський ${ }^{48}$. Більшість його доказів, зокрема дніпроцентричну теорію походження Руси і південне походження назви держави, сприйняв і розвивав у своїх працях один із засадничих радянської концепції Київської Русі Борис Рибаков.

3 розвитком грунтовних джерелознавчих студій наукова неспроможність головних аргументів норманістів ставала щораз очевидніша. Так, історики діййшли висновку, що літописні статті IX ст., пов'язні з утворенням Руси, не завжди вірогідно відображають історичні події. Частина із них була вписана в

\footnotetext{
${ }^{45}$ Вячеслав Фомин. Начальная история Руси.(Москва: Русская панорама, 2008), 8.

${ }^{46}$ Георг Вильгельм. Фридрих Гегель. Сочинения. (Москва:Соцэкгиз, 1935) Т. 8, 97, 323-324.

${ }^{47}$ Василий Ключевский. Наброски по варяжскому вопросу. Неопубликованные произведения. (Москва: Наука, 1983), 113, 119-120.

${ }^{48}$ Михайло Грушевський. Історія Украӥни-Руси (Київ: Наукова думка, 1991) Т. 1, 623-624.
} 
ISSN 2078-6077. Наукові зошити історичного факультету Львівського університету. 2018-2019. Випуск 19-20. Proceedings of History Faculty of Lviv University. 2018-2019. Issue 19-20.

текст пізнішими редакторами ${ }^{49}$. Автори первісного тексту літописного зведення, створеного наприкінці XI - на початку XII ст., - Нестор і Сильвестр - мали лише приблизну уяву про події IX ст., сформовану на основі усних переказів та легенд. Це особливо стосується літописної статті про прикликання варягів, яка лежить в основі норманської теорії. Як відзначав свого часу дослідник літописів Олексій Шахматов, “літописне сказання про прикликання варягів не $є$ вірогідним, воно - домисел учених книжників, які оформили народну традицію у складний літописний переказ" ${ }^{50}$. Подібні сюжети прикликання правителів, зазвичай, $\epsilon$ складним переплетенням історії та мітології і їх не можна сприймати буквально. У спеціяльній науковій розвідці, присвяченій літописному сказанню, О. Шахматов дійшов до висновку, що первісний текст літопису Нестора не містив легенди ${ }^{51}$. Ймовірно, що ііі пізніше вписав у літопис новгородський редактор, намагаючись наголосити провідну роль північних земель i, зокрема, Новгорода в утворенні Руси, адже за легендою Рюрик, Трувор, і Синеус почали правити на півночі - у Ладозі, Ізборську і в Білоозері. Ідею О. Шахматова про появу легенди про прикликання варягів в новгородській редакції ПВЛ підтримав і розвинув Б. Рибаков. Він вважав, що ймовірним редактором, який залучив легенду до літописного тексту, був новгородський князь Мстислав (Гаральд) Володимирович і пояснював це його тісними родинними зв'язками зі скандинавськими правителями. ${ }^{52}$ Сьогодні у джерельній цінності літописної легенди про прикликання варягів сумніваються не лише дослідники ПВЛ, а й прихильники норманізму. ${ }^{53}$ Англійський дослідник Пітер Сойер, наголошуючи на необхідності критичного осмислення джерел, вказував, що середньовічні пам'ятки, зокрема літописи, мають найбільшу цінність для розуміння епохи, коли вони створювалися, і містять багато помилок та неточностей, описуючи давно минули часи ${ }^{54}$. Багаторічні дослідження новгородської археологічної експедиції підтвердили невірогідність літописних повідомлень про те, що Новгород заснував Рюрик у IX ст. Вони встановили, що міста Новгорода на Волхові не існувало до кінця $\mathrm{X}^{55}$, а навіть до середини XI ст. ${ }^{56}$ Розкопане в його

${ }^{49}$ Николай Костомаров. Русская история в жизнеописаниях ее главнейших деятелей. (Москва: Наука, 1991): 53; Алексей Шахматов. Сказание о призвании варягов. (Санкт-Петербург: Типография Императорской Академии наук, 1904) 2; Кузьмин. Начальные этапы древнерусского летописания. Москва: Изд-во МНУ, 1977).85-100, 126, 193; Тетяна Вілкул. Літопис і хронограф. Студії з текстологї̈ до монгольського київського літописання. (Київ: Інститут історії НАН України, 2015): 223-227.

${ }^{50}$ Алексей Шахматов, Сказание о призвании варягов. (СПб, 1904), 47.

${ }^{51}$ Там само, 2.

52 Борис Рыбаков. Мир истории.( Москва: Молодая гвардия, 1984), 17.

${ }^{53}$ Гвин Джонс, Викинги. Потомки Одина и Тора (Москва: Центрполиграф, 2010), 248.

${ }^{54}$ Питер Сойер. Епоха викингов. Пер. с анг. А. П. Санина. (СПб.: Евразия, 2006), 6.

${ }^{55}$ Валентин Янин. Средневековый Новгород. Очерки археологи и истории. (Москва: Наука, 2004),71; Евгений Носов. Новгородское (Рюриково) городище. (Ленинград: Наука, 1990).

56 Леонтій Войтович. Гольмгард: де правили руські князі Святослав Ігоревич, Володимир Святославич та Ярослав Володимирович. Украйнський історичний журнал. Київ, 2015. № 3 (522). 
околицях невелике поселення, яке в XIX ст. норманісти почали називати Рюриковим городищем, за висновком сучасного шведського археолога Інгмара Янссона, не має аналогій серед середньовічних поселень Скандинавії ${ }^{57}$. Інакше кажучи, навряд чи його засновником був скандинав. Істотно послабили позиції норманістів грунтовні дослідження скандинавських писемних пам'яток. Праці Степана Гедеонова і Дмитра Іловайського довели наукову неспроможність версії про шведське походження Рюрика і назви “Русь", оскільки у шведських середньовічних джерелах не було виявлено жодної згадки про легендарного засновника Руси, як і про плем'я русь, від якого нібито пішла назва держави ${ }^{58}$. Історик Густав Еверс характеризував факт цілковитої відсутности згадок про Рюрика і Русь у скандинавських середньовічних джерелах як красномовне мовчання ${ }^{59}$.

Вчений наголошував, що розвиток Руси відбувався на півдні*, де жив народ "рос". "Рюрикове самодержавство" було неважливе, - вказував він, - тому що держава тут "існувала і словом і ділом до єдинодержавства Рюрика"60. С. Гедеонов також наголошував на тому, що мовчання саг, творці яких не упускали можливости описати і реальні, і вигадані подвиги норманів, не може бути випадкове. Адже серед сучасників літописного Рюрика був скальд Тіодольф, пісні якого зберіг Сноррі Стурлуссон. У них згадуються східні венеди, тобто слов'яни, однак немає жодної згадки про “засновника Русі" Рюрика. ${ }^{61}$

Для підтримки норманської версії походження Рюрика, у науковості якої після студій над скандинавськими пам'ятками виникли серйозні сумніви, дерптський професор Фрідріх Крузе висловив припущення про данські корені засновника Руси і ототожнив літописного Рюрика з Рориком Ютландським, який жив у середині IX ст. і згадується у західноєвропейських (франкських) хроніках. Оновлена версія базувалася на джерелі IX ст. - “Житії св. Ансгарія”, у якому повідомляється, що 852 р., після нападу на шведську Бірку, Рорик Ютландський зробив набіг на місто слов'ян ${ }^{62}$. У “Житії” не вказана назва міст, а на південному узбережжі Балтики у той час існувало не одне місто слов’ян (Старіград, Веліград,

37-55; Леонтій Войтович. Хольмгард-Новгород: загадки истории Руси X-первой половины XI века. Вестник Удмуртского университета. Серия 5: История и философия. (Ижевск, 2015). Вып. 1, 7-18.

${ }^{57}$ Ингмар Янссон . Скандинавские находки IX-X вв. Рюрикові городища. Великий Новгород в истории средневековой Европьы. (Москва: Русские словари, 1999), 36.

${ }^{58}$ Степан Гедеонов. Варяги и Русь. Исторические исследования. Ч. ІІ. (СПб.: Типография Императорской академии наук, 1876); Дмитрий Иловайский. Начало Руси. (Москва: Вече, 2015). Электронная Библиотека. loveread.ec/view_globalphp?id=60339

${ }^{59}$ Густав Эверс. Предварительные критические исследования для российской истории. Кн. 2. (Москва: Университетский издательский дом., 1826), 151.

*На думку Еверса, Русь виникла у Причорномор'ї, однак його версія “Причорноморської Русіо не знайшла помітного відгуку в історіографії.

${ }^{60}$ Там само, 83-84.

${ }^{61}$ Степан Гедеонов. Варяги и Русь. Исторические исследования. Ч. II..., 234.

${ }^{62}$ Вячеслав Фомин. Варяги и варяжская Русь, 239. 
ISSN 2078-6077. Наукові зошити історичного факультету Львівського університету. 2018-2019. Випуск 19-20. Proceedings of History Faculty of Lviv University. 2018-2019. Issue 19-20.

Волин, Аркона та ін.), що не поступалося, а навіть перевершувало своїми багатствами шведську Бірку, на яке міг напасти Рорик ${ }^{63}$. Однак, всупереч фактам, зокрема відсутности слідів слов'янського поселення у Ладозі IX ст., норманісти вважають, що слов'янським містом, на яке напав Рорик, була саме вона. ${ }^{64}$. На їх думку, попри різницю в 10 років між походом Рорика (852), описаним у “Житіїо, і літописною легендою про прикликання Рюрика (862), обидві пам’ятки відображають одну і ту ж подію. Супроти ототожнення літописного Рюрика 3 Рориком Ютландським свідчить і той факт, що, як відомо з франкських хронік, у 863 р. (і пізніше) Рорик Ютландський воював у Фрисландії на Райні і аж ніяк не міг розбудовувати у Ладозі Руський каганат. На думку російського дослідника Володимира Яманова, саме широка відомість Рорика Ютландського на Заході робить його появу в Приладожжі дуже сумнівною, оскільки така далека експедиція відомої людини не могла залишитися поза увагою хроністів. Але у хроніках про неї немає жодного натяку ${ }^{65}$.

Прихильники норманської теорії підхопили данську версію Крузе попри те, що вона повністю зруйнувала первісний шведський варіянт походження Руси. Свого часу відомий скандинавіст Олена Ридзєвська вказувала, що через свою надуманість і бездоказовість гіпотеза Крузе навіть не заслуговує на увагу істориків ${ }^{66}$. Однак сучасні норманісти продовжують ії використовувати у своїх конструкціях міфічної північної Руси, тепер уже 3 центром у Ладозі ${ }^{67}$. Версію данського походження засновника руської династії Рюрика вони дивно поєднують 3 версією шведського походження назви “Русьо, створюючи таку собі скандинавську химеру. Після того, як дослідники шведських джерел з'ясували, що етнонім "русь" у них жодного разу не згадується, норманісти повернулися до версії, яку свого часу розкритикував М. Ломоносов. Згідно з нею, назва "русь" походить від фінської назви (“Ruotsi”) для частини шведського узбережжя

63 Див.: Ольга Щодра. Епоха вікінгів у Східній Європі: слов’янсько-скандинавські звязки в період формування ранніх слов'янських держав Проблеми слов'янознавства. (2017). Вип. 66, 927.

${ }^{64}$ Анатолий Кирпичников, Виктор Сарабьянов. Старая Ладога - древняя столица Руси. (Санкт-Петербург: Славия, 2010): 83-84.

${ }^{65}$ Владимир Яманов, “Рорик Ютландський и летописный Рюрик”, Bonpocы истории. № 4, 2002, 127-137.

${ }^{66}$ Елена Рыдзевская. “О роли варягов в Древней Руси”. Древняя Русь и Скандинавия в IX$X I V$ вв. (Москва: Наука, 1978), 148.

${ }^{67}$ Дмитрий Мачинский. Волховская Русь (VIII-IX вв.). Современность и археология. Международные чтения, посвященные 25 летию Староладожской археологической экспедиции. (Санкт-Петербург: Староладожский историко-архитектурный и археологический музейзаповедник, 1997), 71-75; Мачинский... Почему и в каком смысле Ладогу следует считать первой столицей Руси. Ладога и Северная Евразия от Байкала до Ла-Манша. Связующие пути и центры. Шестые чтения памяти Анны Мачинской. (Санкт-Петербург, Староладожский историкоархитектурный и археологический музей-заповедник, 2002), 5-35; Кирпичников, Сарабьянов. Старая Ладога - древняя столицуа Руси, 83-84. 
(Roslagen), розташованого навпроти Фінляндії. Однак дослідження встановили, що назва шведського узбережжя “Roslagen” з'явилася лише у XIII ст., оскільки раніше цього узбережжя просто не існувало, а його територія ще була дном моря $^{68}$. Фінська ж назва "Ruotsi”, для означення цієї шведської области фіксується ще пізніше - у XVI-XVII ст., оскільки раніших пам'яток фінської мови немає ${ }^{69}$. Сучасні скандинавські філологи також заперечують будь-який зв'язок між назвами "Русь" і "Рослаген"70.

Як свідчать закордонні писемні джерела, а саме: візантійські “Житія” Стефана Сурозького ${ }^{71}$ і Георгія Амастрідського ${ }^{72}$, франкська Бертинська хроніка ${ }^{73}$ назва "Русь” (“руси”, “роси”) була відома уже наприкінці VIII - на початку IX ст., тобто, значно раніше середини IX ст., коли вона вперше згадується у ПВЛ. Про русів, про їх морські походи в першій половині IX ст. по Чорному і Каспійському морях та міжнародні торговельні зв'язки, що простягалися на схід до Багдаду і на захід до Андалусії, повідомляють також арабські автори ${ }^{74}$. У Бертинських анналах - хроніці франкських королів -згадується посольство від народу “рос" до Візантії та Імперії Каролінгів у 838-839 pр. Автор хроніки і сучасник подій Пруденцій вказує, що король русів мав титул “хакан”, який в тюркській титулатурі означав імператора ${ }^{75}$. Усі ці факти переконливо засвідчують існування Руської держави наприкінці VIII - в першій половині IX ст. тобто за півстоліття до датування літописної легенди про прикликання варягів. Як уже говорилося, стержнем норманської теорії є уявлення, що закріпилися в історіографії з часів Г. Баєра, про тотожність варягів і норманів. Вони були характерні і для більшости представників радянської історіографії (як і уява про існування північної Новгородської Руси), і значною мірою є характерні для сучасної східноевропейської історіографії.

68 Лидия Грот. Призвание варягов. Норманы, которах не было. (Москва: Алгоритм, 2013), 99-115.

${ }^{69}$ Игорь Шаскольский. Вопрос о происхождении имени “Русь” в современной буржуазной науке. Критика новейшей буржуазной историографии. (Лениград: Наука, 1967) 156, 158, прим. $10,114$.

${ }^{70}$ Хокун Станг. Наименование Руси (герульская версия). (СПб.: Евразия, 2000), 62-66.

71 Юрий Могарычев, Андрей Сазанов, Елена Степанова, Андрей Шапошников. Житие Стефана Сурожского в контексте истории Крыма иконоборческого времени.(Симферополь: АнтиквА, 2009), 11-76.

72 Житие Георгия Амастридского. Древняя Русь в свете зарубежных источников. Т. 2. Византийские источники. (Москва: Русский фонд содействия образованию и науке, 2010), 129130.

${ }^{73}$ Annales Bertinia. Prudentii Tresensis episcopi, annales a 835-861. Monumenta Germaniae Historica. T. 1: Annales et chronica aevi Carolini. (Leipzig, 1925), 434.

${ }^{74}$ Ибн-Хордадбех. Книга путей и стран. Пер. с араб., комментарии, исследования Н. Велихановой. (Баку: ЭЛМ, 1986), 39.

75 Див.: Ольга Щодра. Коли і де виникла Русь: проблеми початкового етапу формування української державності. Вісник НТШ. № 58. (осінь-зима 2017), 31-37. 
ISSN 2078-6077. Наукові зошити історичного факультету Львівського університету. 2018-2019. Випуск 19-20. Proceedings of History Faculty of Lviv University. 2018-2019. Issue 19-20.

Однак джерела не дають підстав для такої однозначної етнічної атрибуції варягів як скандинавів. Автори середньовічних творів часто по-різному передавали назви і самоназви народів, що спричиняє плутанину і утруднює студії етнічної історії середньовіччя. Однак не меншу роль у сумнівному трактуванні етнонімів відігравали і відіграють суб'єктивні уподобання дослідників. Термін “варяги" (“варанги”) вперше згадуються у візантійському джерелі в середині XI ст. ( в імператорському хрисовулі 1060 р., що звільняв від постою військових загонів), як військові найманці, тоді як етнонім “русь” був відомий візантійським авторам уже 3 початку IX ст. Така розбіжність у два століття виглядає незрозумілою на випадок, якщо б обидва терміни мали однакову етнічну атрибуцію і означали норманів. 3 тексту хрисовула зрозуміло, що варягами візантійці називали військових найманців. Норманісти вважають, що цей термін означав скандинавського найманця ${ }^{76}$. Виникає закономірне питання: чому термін, що означав військових найманців-скандинавів, з'явився у візантійській хроніці лише в XI ст., адже руси (згідно з версією норманістів - теж скандинави) наймалися у візантійське військо вже в першій половині X ст. Тобто, версія скандинавського походження терміну викликає сумніви.

У ПВЛ варяги вперше згадуються у 862 р. в легенді про прикликання Рюрика, Трувора і Синуса ${ }^{77}$. Зі статті 882 р. дізнаємося, що вони були у війську князя Олега під час походу на Смоленськ, Любеч і Київ ${ }^{78}$, у 941 р. князь Ігор, готуючись до походу проти Візантії, також "послав за варягами за море"79.

Отже, руські правителі набагато раніше від візантійського імператора почали користувалися послугами найманців варягів. Військове найманство скандинавів до руських князів у IX-першій половині X ст. важко пояснити, оскільки вони не були географічними сусідами Дніпровської Русі і, як свідчать скандинавські джерела, до кінця X ст. практично не цікавилися Східною Европою та майже нічого не знали про Русь ${ }^{80}$. Переконливіше пояснює цю ситуацію інша версія походження варягів. Як уже згадувалося, в европейській історіографії до XVIII ст. варягами називали вихідців із слов'янської області Вагрії, розташованої на південному узбережжі Балтики. Окрім барона С. Герберштайна, на

\footnotetext{
${ }^{76}$ Елена Мельникова, Владимир Петрухин. Скандинавы на Руси и в Византии в X-XI веках: К истории названия “варяг”. Славяноведение, 2 (1994), 56-68; Мельникова. Варяжская доля. Родина. 11-12 (2002): 30-32; Владимир Петрухин. “От тех варяг прозвася...” Родина. 10 (1997). 4-16; Владимир Петрухин. Начало этнокультурной истории Руси IX-XI веков. (СмоленскМосква: 1995): 109, 242-243.

77 Повесть временных лет. По Ларентиевской летописи 1377 г. (Москва-Ленинград: Издательство Академии Наук СССР, 1950), 18.

${ }_{78}^{78}$ Там само, 20.

${ }^{79}$ Там само, 33.

80 Елена Мельникова. Скандинавские рунические написи. Нове находки и интерпретации.(Москва: Восточная литература, 2001) 23-24; Мельникова. Рунические написи. Древняя Русь в свете зарубежных источников. (Москва: Русский Фонд Содействия Образованию и Науке,2009). Т. 5: 21-24.
} 
південнобалтійське походження варягів вказували й інші історики XVI-XVII ст. ${ }^{81}$ Особливо цікавою щоб з'ясувати проблему походження варягів, є “Космографія” Себастьяна Мюнстера (Базель, 1628), який на замовлення Густава II Вази писав історію шведських королів і мав офіційний заказ возвеличити усіх давніх правителів Швеції. Попри те, у своїй праці він ніяк не пов'язував варягів зі шведами, а шведів - з руською династією і Рюриком. Автор "Синопсисуо Інокентій Гізель (1674р.) також вказував, що варяги сиділи над Балтійським морем, яке від них отримало назву Варязького, і говорили слов' янською мовою ${ }^{82}$. Версії про зв'язок варягів з південнобалтійськими слов'янами дотримувалися й інші відомі автори - Августин Майерберг, Матей Стрийковський. ${ }^{83}$ Іїі грунтовно розроблялали в російській історіографії ХІХ ст. ${ }^{84}$ і продовжують розробляти в сучасній ${ }^{85}$.

Південнобалтійська область Вагрія була частиною племінної території слов'янського союзу ободритів, які у ранньому середньовіччі разом із слов'янськими об'єднаннями лютичів-велетів і поморян заселяли землі між Віслою, Одрою та Лабою і брали активну участь у міжнародній балтійській торгівлі VIII-IX ст. ${ }^{86}$ Придворний історіограф герцогства БрауншвейгЛюнебурзького і Ганноверського, яке охоплювало землі ободритів і вагрів, Готфрід Вільгельм Лайбніц писав, що батьківщиною варягів могла бути лише "Вагрія, область, в якій розташовується місто Любек, і яка раніше була вся заселена слов'янами - ваграми, ободритами і ін... завжди була країною 3 обширною торгівлею, навіть до заснування Любека, а тому назва цієї країни легко могла зробитися назвою всього моря"в7.

На території ободритів були великі, як для того часу, міські центри, зокрема у Вагрії - Старіград (пізніше - нім. Ольденбург) ${ }^{88}$, княжа резиденція Веліград (Магнополіс у латинських джерелах), який Адам Бременський називав Рериком,

81 Див.: Вячеслав Фомин. Начальная история, 190-193; Владислав Меркулов. Откуда родом варяжские гости?, 26-28.

${ }^{82}$ Синопсис. (СПб.: Императорская Академія наук, 1762), 22.

${ }^{83}$ Августин Майерберг . Путешествие в Московию. (Москва: Общество истории и древностей российских при Московском унивесритете, 1874), 105; Kronika Polska, Litewska, Zmodska i wszystkiej Rusi Macieja Stryjkowskiego. (Gluckberg, 1846) t. 1, 113. Доступ отримано 10 листопада 2018 p. https://books.google.com/.../Kronika Polska_Litewska_Zmodzka I wszy.htm

${ }^{84}$ Степан Гедеонов. Варяги и Русь. Исторические исследования. Ч. ІІ.

${ }^{85}$ Див.: Аполлон Кузьмин. Начало Руси: Тайны рождения руського народа; Вячеслав Фомин. Варяги и варяжская Русь. К итогам дискуссии по варяжскому вопросу. Москва: Русская панорама. 2005; Лидия Грот. Призвание варягов. Норманы, которах не было; Лидия Грот, Призвание варягов.Норманская лжетеория и правда о князе Рюрике и др.

86 Див.: Ольга Щодра. Епоха вікінгів у Східній Європі: слов'янсько-скандинавські зв'язки в період формування ранніх словянських держав. Проблеми слов'янознавства. (2017). Вип. 66, 13.

${ }^{87}$ Цитую по: Владимир Герье, Лейбнии и его век. Отношение Лейбница к России и Петру Великому по неизданным бумагам Лейбница в Ганноверской библиотеке. (СПб.: Печатня В. И. Головина, 1871), 102.

${ }^{88}$ Гельмольд. Славянские хроники. (Москва: Издательство АН СССР, 1963$), 37$. 
ISSN 2078-6077. Наукові зошити історичного факультету Львівського університету. 2018-2019. Випуск 19-20. Proceedings of History Faculty of Lviv University. 2018-2019. Issue 19-20.

а самих ободритів - ререгами ${ }^{89}$. Отже, не випадково першою в европейській історіографії була версія ободрицького походження літописного Рюрика. У XVIXVII ст. іiі обгрунтовували німецькі історики, зокрема дослідники генеалогії Бернхард Латом і Йоган Хемніц, які вважали Рюрика сином ободрицького князя Годліба, вбитого данцями у 808 р. під час взяття міста Рерик. ${ }^{90}$ На початку XVIII ст. Йоган Гюбнер у своїх знаменитих “Генеалогічних таблицях" доводив, що Рюрик $є$ нащадком венедо-ободрицьких королів ${ }^{91}$.

Версія ободритського походження Рюрика також має прихильників серед сучасних дослідників. Так, П. Толочко припускає, що Рюрик міг походити 3 ободрицького міста Рерика, що пояснює його ім'я, оскільки в середньовіччі людина часто набувала ім'я міста або країни, звідки вона походила, як наприклад король Бірки - Берка ${ }^{92}$. Ободрицьким правителем вважають Рюрика також російські дослідники Андрій Нікітін (виводить ім’я Рюрик від “ререг” (рарог) сокіл, священної птиці і символу ободритів, яких сучасники ще називали "ререгами") ${ }^{93}$ і Владислав Меркулов ${ }^{94}$.

Не однозначно інтерпретують середньовічні автори і термін “нормани”. Він мав не так етнічне, як географічне значення - "північні людио i, залежно від місця замешкання автора, цими північними людьми могли виступати мешканці різних европейських регіонів. Так, західнофранкські хроністи називали норманами мешканців сучасної Скандинавії (за півостровом ця назва закріпилася лише в XVI ст.). У такому ж значенні назву “нормани”, “урмани” використовували руські літописці. Однак для Ліудпранда Кремонського, головного латинського історика $\mathrm{X}$ ст., єпископа Кремони, розташованої на той час у франкській (північній) Італії, "норманами" (Nordmanni) або "північними людьми” були усі народи на північ від Дунаю. Так, у “Книзі покарань' (“Антаподосіс”), описуючи похід руського князя Ігоря на Візантію в 941 р., він писав, що “Константинополь ... розташований серед злих народів ... 3 півночі його найближчими сусідами є угри , печеніги, хозари, русь, яку інакше ми називаємо нордманами, а також болгари ...”. Далі про русів він повідомляє таке: “...ннарод, який греки по зовнішньому виду називає руссю, ми ж по місцезнаходженню називаємо нордманами (північними людьми).

\footnotetext{
${ }^{89}$ Адам Бременський, Гельмольд из Босау, Арнольд Любекский. Славянские хроники. (Москва: Русская панорама, 2011), 41.

${ }^{90}$ Готлиб Байер, География российская и соседних с Россией областей около 947 года из книг северных писателей выбрана. Пер. с нем. Кириака Киндратовича. (СПб.:Типография Императорской Академии наук, 1767), 3, 46.

${ }^{91}$ Jogan Hubner. Genealogische Tabellen, nebst denen darzu Gehonigen genealogischen Fragen. T. 1. (Leipzig. 1725), 281, 112 Tab.

${ }_{92}$ Петро Толочко. Київська Русь. (Київ: Абрис, 1996), 46.

${ }_{93}^{93}$ Андрей Никитин. Первый Рюрик - миф или реальность. Наука и религия. 4, (1991), 36-38; Никитин. Основание русской истории. Мифологемы и факты. (Москва: Аграф, 2001), 148169.

${ }^{94}$ Владислав Меркулов. Откуда родом варяжские гости?, 94.
} 
Адже німецькою мовою норд означає північ, а ман -людина; тому-то північних людей і можна називати норманами"95. Отже, в географічній уяві Ліудпранда північчю (щодо Італії) були землі за Дунаєм, а північними людьми або нордманами зовсім не норвежці, шведи або дани, а руси, печеніги, хозари і угри.

Загалом треба констатувати, що до початку XX ст. фонд писемних джерел щоб розв'язати норманську проблему в основному був вичерпаний, а аргументи норманської теорії, що базувалися на писемних джерелах, - значною мірою спростовані*. Виникає питання: чому в історіографії знову спостерігаємо відродження версій та аргументів норманізму, наукова неспроможність яких уже доведена? 3 російською історіографією усе більш-менш зрозуміло: норманська теорія дає єдину можливість для конструкції Північної Руси, яку так хочуть бачити на своій території російські дослідники. Що ж до вітчизняної історіографії, у якій також набирає популярності норманізм ${ }^{96}$, то, можливо, у такий спосіб реалізується бажання вписати історію Руси в загальноевропейський історичний контекст, зокрема в епоху вікінгів. Однак оцінка ролі норманів в европейській історії зараз зазнає істотної корекції. Романтизація і героїзація епохи вікінгів поволі відходять у минуле, оскільки вони є продуктом некритичного опрацювання середньовічних джерел, зокрема скандинавських саг, і перешкоджають об'єктивному дослідженню і розумінню епохи. Як вказує сучасна дослідниця Тетяна Джаксон, найбільш ранні саги були створені лише у XII ст., а дійшли до нас у ще пізніших списках (XIII - XIV ст. $)^{97}$. Майже століття саги поширювалися в усній традиції, вбираючи напівфантастичні сказання та міти, за якими дуже важко розпізнати реалії епохи вікінгів і датувати їх. А тому дослідники, які працювали з сагами i некритично сприймали їх інформацію, часто переносили факти та події пізнішої скандинавської історії на ранній період епохи вікінгів. Сучасний англійський історик П. Сойер в грунтовному аналізі середньовічних джерел з історії походів вікінгів також наголошував на необхідності критично оцінювати їх та проілюстрував на конкретних прикладах, які грубі помилки допускали середньовічні автори і редактори хронік, датуючи події, визначаючи чисельність суден та загонів

\footnotetext{
95 Лиудпранд Кремонский. Книга вомездия (“Антаподосис”). Древняя Русь в свете зарубежных источников. T.V.(Москва: Русский фонд содействия образованию и науке, 2010), 37-38.

* У XX ст. до “розв'язання" норманської проблеми були залучені археологічні джерела і на їх основі виникли нові версії норманської теорії, зокрема колонізаційна, творцями якої були шведські археологи Туре Арне і Хольгар Арбман.

${ }^{96}$ Див.: Федір Андрощук. Нормани і слов'яни у Понесенні. Моделі культурної взаємодії доби раннього середньовіччя (Київ: Товариство археології та антропології, 1999); Володимир Зоценко. “Гнездово в системе связей Среднего Поднепровья IX-X вв." Гнездово. 125 лет исследования памятника. (Москва: ГИМ, 2001):121-125;

${ }^{97}$ Татьяна Джаксон, Четыре норвежских конунга на Руси: Из истории русско-норвежсских политических отношений последней трети $X$-первой половины XI в. (Москва: Языки русской культуры, 2000), 2; Татьяна Джаксон, Русь глазами средневековых скандинавов, Мир истории. 4-5 (2002), 51.
} 
ISSN 2078-6077. Наукові зошити історичного факультету Львівського університету. 2018-2019. Випуск 19-20. Proceedings of History Faculty of Lviv University. 2018-2019. Issue 19-20.

норманів (в бік їх значного перебільшення) ${ }^{98}$. Ці помилки виникали і у процесі неодноразового переписування хронік, і внаслідок дуже упередженого ставлення авторів, як правило вихідців із церковного середовища, до вікінгів, що нещадно грабували і нищили церкви та монастирі.

Щодо державотворчої ролі норманів у Східній Европі, то сучасні західні історики, керучись фактами, також оцінюють їі доволі скептично. Так, німецький дослідник Йоахим Геррман вказує, що “питання про роль норманів у державотворчих процесах на континенті дуже дискусійне. Не було б нічого дивного в тому, що і в Східній Европі окремі загони норманів іноді могли домогтись таких успіхів, як і в феодальних державах Західної Европи, де їм вдавалося засновувати більш чи менш самостійні володіння. Але в обидвох випадках ці тимчасові військово-політичні утворення не слід ототожнювати із створенням місцевої династії, як це роблять норманісти"я9.

\title{
BETWEEN NORMANISM AND ANTI-NORMANISM: DISCUSSIONS ABOUT THE ORIGIN OF RUTHENIA IN THE LIGHT OF WRITTEN SOURCES
}

\author{
Olga SHCHODRA \\ Ivan Franko National University of Lviv \\ Department of Ancient History of Ukraine and Archive Study \\ Universytetska str. 1, Lviv, 79000, Ukraine \\ e-mail: olgashchodra@gmail.com
}

Modern polemics around the problem of the origin of Ruthenia has a long tradition. Russian official historiography began in the 18th century, together with the statement of the Russian Empire on the discussion of the initial history of the Russian state. In its formation and in the formation of Normanism as a leading area of research in the history of Ruthenia, the important part was played by German scientists Gottlieb Baer, Gottfried Miller and August Schlosser, who developed the idea of the decisive participation of the Scandinavians in its founding, which was the theory, initiated by Swedish historians of the XIII century. The widespread Normanism in European historiography was also significantly developed by the French educator Charles Louis Montesquieu and the German philosophers Johan Fichte and especially Georg Hegel. Simultaneously with the Norman theory of the origin of Ruthenia, they developed Anti-Normanist trend in historiography, the beginning of which was debated by Mikhail Lomonosov with Miller at the meetings of the Imperial Academy of Sciences. Until the beginning of the twentieth century, representatives of both directions of historiography used mostly written sources. In the writings of Lomonosov, Evers, Gedeonov, Ilovaysky most of the arguments of the classical Norman theory, in particular about the Swedish origin of the founder of the Ruthenian dynasty Rurik and the name "Rutheniaî, had been refuted, but they are still used today by Russian historians in order to prove the northern origin of Ruthenia (the so-called Ladoga Ruthenian Kaganate) Assessing the role of the Normans in European history is now undergoing significant correction. Romanticization and

\footnotetext{
${ }^{98}$ Питер Сойер. Епоха викингов. Пер. с анг. А. П. Санина. (СПб.: Евразия, 2006), 6-8.

${ }^{99}$ Йоахим Херрман. “Славяне и скандинавы в ранней истории Балтийского региона.” Славяне и скандинавы. (Москва: Прогрес, 1986), 104.
} 
ISSN 2078-6077. Наукові зошити історичного факультету Львівського університету. 2018-2019. Випуск 19-20. Proceedings of History Faculty of Lviv University. 2018-2019. Issue 19-20.

heroization of the Viking era gradually go away in the past, as they are the product of uncritical work of medieval sources and impede the objective study and understanding of the era In general, it should be noted that by the beginning of the twentieth century, the fund of written sources for solving the Norman problem was largely exhausted, and the arguments of the Norman theory, based on written sources, were largely refuted.

Keywords: theory, Normanists, historiography, origin, Russia.

\section{REFERENCES}

Annales Bertinia. "Prudentii Tresensis episcopi, annales a 835-861. Monumenta Germaniae Historica" t.1: Annale et chronica aevi Carolini. Leipzig, 1925. (in Latin).

Androshchuk, Fedir. Normany i slovyany u Ponesenni. Modeli kulturnoyi vzayemodiyi doby rannoho serednovichchya. Kyiv: Tovarystvo arkheolohiyi ta antropolohiyi, 1999. (in Ukrainian).

Bayer, Hotlyb. Heohrafyya rossiyskaia y sosednykh s rossyey oblastey okolo 947 hoda iz knyh severnykh pysateley vybrana. Per. s nem. Kyryaka Kyndratovycha. SPb.: Typohrafyya Imperatorskoy Akademyy nauk, 1767. (in Russian).

Bremenskyy, Adam, Helmold yz Bosau, Lyubekskyy Arnold. Slavyanskye khroniky. Moskva: Russkaya panorama, 2011. (in Russian).

Bestuzhev-Ryumyn, Kostyantyn. Russkaia istoria. SPb.: Izdatelstvo D. E. Kozhanchykova, 1872 t. 1. (in Russian).

Bestuzhev-Ryumyn, Konstantyn "Byohrafii i kharakterystyki (letopystsy Rossii).” Moskva: VEK, 1997. (in Russian).

Vilkul, Tetyana. Litopys i khronohraf. Studiyi z tekstolohiyi do monholskoho kyyivskoho litopysannya. Kyiv: Instytut istoriyi NAN Ukrainy, 2015. (in Ukrainian).

Voytovych, Leontiy. "Holmhard: de pravyly ruski knyazi Svyatoslav Ihorevych, Volodymyr Svyatoslavych ta Yaroslav Volodymyrovych." Ukrayinskyy istorychnyy zhurnal. 3(522). Kyiv, 2015. 37-55. (in Ukrainian).

Voytovych, Leontiy. "Kholmhard-Novhorod: zahadky istorii Rusy X-pervoy poloviny XI veka." Vestnyk Udmurt.skoho unyversyteta. Seryya 5: Istoriia y fylosofyya. (Izhevsk, 2015). Vyp. 1, 7-18. (in Russian).

Hehel, Heorh Vylhelm Frydrykh. Sochynenyya. Moskva: Sotsék·hyz, 1935. t. 8. (in Russian).

Helmold, Slavyanskye khronyky. Moskva: Izdatelstvo AN SSSR, 1963. (in Russian).

Here Vladymyr. Leybnyts y eho vek. Otnoshenye Leybnytsa k Rossii i Petru Velykomu po neyzdannym bumaham Leybnytsa $v$ Hannoverskoy byblyoteke. SPb.: Pechatnya V. Y. Holovyna, 1871. (in Russian).

Dzhons, Hvyn. Vykynhy. Potomky Odyna y Tora. Per. s anhl. Z. YU. Metlytskoy. Moskva: Tsentrpolyhraf, 2010. (in Russian).

Hrot, Lidiya. Pryzvanye varyahov. Normany, kotorykh ne bylo. Moskva: Alhorytm, 2013. (in Russian).

Hrot, Lidiya. "Myfoloycheskye y realnye shvedy na severe Rossii: vzhlyad iz shvedskoy istorii”. Shvedy i Russkiy Sever: istoryko-kulturnye sviazi. Materialy mezhdunarodnoho simpoziuma 210 letiyu Aleksandra Lavrentyevicha Vytberha. Vzd-vo Kirov,1997, 153158. (in Russian).

Hrot, Lidiya. Pryzvanye variahov. Normanskaya lzheteoriya i pravda o knyaze Ryurike. Moskva: Alhorytm, 2012. (in Russian). 
ISSN 2078-6077. Наукові зошити історичного факультету Львівського університету. 2018-2019. Випуск 19-20. Proceedings of History Faculty of Lviv University. 2018-2019. Issue 19-20.

Hrushevskyy, Mykhaylo. "Zvychayna skhema "russkoy istoriyi y sprava ratsionalnoho ukladu istoriyi skhidnoho slov’yanstva. ” Ukrayinskyy istorychnyy zhurnal. Vyp. 5. (2014), 199208. (in Ukrainian),

Hrushevskyy, Mykhaylo. Istoria Ukrainy-Rusy. Kyiv: Naukova dumka, 1991 t. 1. (in Ukrainian).

Dalyn, Olaf. Istoria shvedskoho hosudarstva. CH.1. Kn.1. Spb.: Imperatorskaya typohrafiia, 1805. (in Russian).

Stepan Hedeonov. Varyahy i Rus. Istoricheskye issledovaniya. CH. II. SPb.: Typohrafiya Imperatorskoy Akademiyi Nauk, 1876. (in Russian).

Dzhakson, Tatyana. Chetyre norvezhskykh konunha na Rusy: Iz istorii russko-norvezhskykh polyticheskikh otnosheniy posledney treti X-pervoy poloviny XI v. Moskva: Iazyky russkoy kultury, 2000.

Dzhakson, Tatyana. "Rus hlazamy srednevekovykh skandynavov." Mir istorii. 4-5 (2002). 48-58. (in Russian).

Zhytye Heorhyya Amastrydskoho Per. s hrech. V. H. Vasylevskoho. Drevnyaya Rus v svete zarubezhnykh istochnykov. T. 2. Vyzantiyskye istochniky. Moskva: Russkiy fond sodeystviya obrazovaniyu y nauke, 2010, 127-129. (in Russian).

Zabelyn, Ivan. Istoriya russkoy zhyzni s drvneyshykh vremen. CH.I. Moskva: Typohrafiya Hracheva, 1876. (in Russian).

Zapisky o Moskovii Barona Herbershteyna, Per. s nem. Y. Anonymova. S.-Peterburh: Typohrafiya Bezobrazova i komp. 1866. (in Russian).

Zemtsov, Boris. "Otkuda yest' poshla rosiyskaia tsivilizatsiya”, Obshchestvennyye nauki $i$ sovremennost'. Moskva, 4 (1994). 48-56. (in Russian).

Zotsenko, Vladimir. “Gnezdovo v sisteme svyazey Srednego Podneprov’ya IX vv”. Gnezdovo. 125 let issledovaniya pamyatnika. (Moskva: GIM), 2010. ). (in Russian).

Ívakín, Glíb. Opovidí pro starodavníy Kyiv. Kyiv: Radyans'ka shkola, 1982. (in Ukrainian).

Ivakin, Ivan. Kniaz' Vladimir Monomakh i yego poucheniye. CH.1. Moskva:Universytetskaya tipografiya. Strastnoy bul'var, 1901. (in Russian).

Ilovayskiy, Dmitriy. "Nachalo Rusi” Moskva: Veche, 2015. Elektronnaia Biblioteka. https:// loveread.ec/view_globalphp?id=60339 (in Russian).

Istoriya Shvetsii. Otv. red. A. S. Kan. Moskva: Nauka, 1974. (in Russian).

Evers, Gustav. Predvaritel'nyye kriticheskiye issledovaniya dlya rossiyskoy istorii. Kn. 2. Moskva: Universytetskiy izdatel'skiy dom, 1826. (in Russian).

Kirpichnikov, Anatoliy, Sarab'yanov, Viktor. Staraya Ladoga - drevnyaya stolitsa Rusi. SanktPeterburg: Slaviya, 2010. (in Russian).

Klyuchevs'kiy, Vasiliy. Nabroski po varyazhskomu voprosu. Neopublikovannyye proizvedeniya. Moskva: Nauka, 1983. (in Russian).

Kostomarov, Nikolay. Russkaya istoriya v zhizneopisaniyakh yeyo glavneyshikh deyateley. Moskva: Nauka, 1991. (in Russian).

Kronika Polska, Litewska, “Zmodska i wszystkiej Rusi Macieja Stryjkowskiego. Gluckberg”, 1846. t. 1 Elektronna biblioteka. dostup otrymano 10 lystopada 2018 r. https:// books.google.com/.../Kronika Polska_Litewska_Zmodzka I wszy.htm (in Polish).

Kremonskiy, Liudprand. Kniga vomezdiya ("Antapodosis”). Drevnyaya Rus'v svete zarubezhnykh istochnikov T.V. Moskva: Russkiy fond sodeystviya obrazovaniyu i nauke, 2010. (in Russian).

Kuz'min, Apollon. Nachal'nyye etapy drevnerusskogo letopisaniya. Moskva: Izd-vo MGU, 1977. (in Russian). 
ISSN 2078-6077. Наукові зошити історичного факультету Львівського університету. 2018-2019. Випуск 19-20. Proceedings of History Faculty of Lviv University. 2018-2019. Issue 19-20.

Kuz'min, Apollon. Nachalo Rusi: Tayny rozhdeniya rus 'kogo naroda. Moskva: Veche, 2003. (in Russian).

Lomonosov, Mikhail. Polnoye sobraniye sochineniy. Moskva-Leningrad: Izdatel'stvo AN SSSR, 1952. t. 6. (in Russian).

Machinskiy, Dmitrik. "Volkhovskaya Rus". Sovremennost'i arkheologiya. Mezhdunarodnyye chteniya, posvyashchennyye 25 letiyu Staroladozhskoy arkheologicheskoy ekspeditsii. Sankt-Peterburg: Staroladozhskiy istoriko-arkhitekturnyy i arkheologicheskiy muzeyzapovednik, 1997, 5-35. (in Russian).

Machinskiy, Dmitriy. "Pochemu i v kakom smysle Ladogu sleduyet schitat pervoy stolitsey Rusi". Ladoga i Severnaya Yevraziya ot Baykala do La-Mansha. Svyazuyushchiye puti i tsentry. Shestyye chteniya pamyati Anny Machinskoy. Sankt-Peterburg, Staroladozhskiy istoriko-arkhitekturnyy i arkheologicheskiy muzey-zapovednik, 2002, 5-37. (in Russian).

Mayyerberg, Avgustin. Puteshestviye v Moskoviyu. Moskva: Obshchestvo istorii i drevnostey rossiyskikh pri Moskovskom univesrytete, 1874. (in Russian).

Mel'nikova, Yelena, Petrukhin, Vladimir. "Skandinavy na Rusi i v Vizantii v XII - XIII vekakh: K istorii nazvaniya "varyag". Slavyanovedeniye, 2 (1994), 56-68. (in Russian).

Mel'nikova, Yelena. Skandinavskiye runicheskiye napisi. Novyye nakhodki i interpretatsii. Moskva: Vostochnaya literatura, 2001. (in Russian).

Mel'nikova, Yelena. "Varyazhskaya dolya". Rodina. 11-12 (2002). 30-32; (in Russian).

Mel'nikova, Yelena. Runicheskiye napisi. Drevnyaya Rus'v svete zarubezhnykh istochnikov. Moskva: Russkiy Fond Sodeystviya Obrazovaniyu i Nauke, 2009. T. 5, 21-24. (in Russian).

Miller, Gotfrid O narodakh izdrevle v Rossii obitavshikh. Per. s nem. Ivana Dolinskogo. 2-ye $i z d$. SPb.: Tipografiya pri Imperatorskoy Akademii nauk, 1788. (in Russian).

Merzeburgskiy, Titmar. Khroniki (1012-1018). Drevnyaya Rus'v svete zarubezhnykh istochnikov. Moskva: Russkiy Fond Sodeystviya Obrazovaniyu i Nauke, 2010. T. 4, 83. (in Russian).

Merk ulov, Vladislav. Otkuda rodom varyazhskiye gosti? Genealogicheskaya rekonstruktsyya po nemetskim istochnikam. Moskva. 2005. Rezhim dostupu: old- earthnarodru/lib/slav/ balt/merkulovearthnarodru/lib/slav/balt/merkulov-varangian-guests.pdf. (in Russian).

Mogarychev, Yuriy, Sazanov, Andrey, Stepanova, Yelena, Shaposhnikov, Andrey. Zhitiye Stefana Surozhskogo v kontekste istorii Kryma ikonoborcheskogo vremeni. Simferopol: AntikvA, 2009. (in Russian).

Molchanov, Arkadiy. Drevneskandinavskiy antroponimicheskiy element $v$ dinasticheskoy traditsii roda Ryurikovichey. Obrazovaniye Drevnerusskogo gosudarstva: spornyye voprosy. Moskva: Nauka, 1992, 44-47. (in Russian).

Montesk'ye, Sharl' Lui. Izbrannyye proizvedeniya o dukhe zakonov. Moskva: Gospolitizdat, 1955. (in Russian).

Moshin, Vladimir. "Varyago-russkiy vopros. Varyago-russkiy vopros v istoriografii”" red. Vyacheslav Fomin (Moskva: Russkaya panorama, 2010), Istoricheskaya biblioteka, dostup otrymano 31 grudnya 2016. http://historylib.org/historybooks/Fomin_Varyago-Russkiyvopros-v-istoriografii/2. (in Russian).

Nikitin, Andrey. "Pervyy Ryurik - mif ili real'nost'”. Nauka i religiia. 4 (1991). 36-39. (in Russian).

Nikitin, Andrey. Osnovaniye russkoy istorii. Mifologemy i fakty. Moskva: Agraf, 2001. (in Russian). 
ISSN 2078-6077. Наукові зошити історичного факультету Львівського університету. 2018-2019. Випуск 19-20. Proceedings of History Faculty of Lviv University. 2018-2019. Issue 19-20.

Nosov, Yevgeniy. Novgorodskoye (Ryurikovo) gorodishche. Leningrad: Nauka, 1990. (in Russian).

Povest'vremennykh let. Po Lavrentiyevskoy letopisi 1377 g. Tekst. Moskva-Leningrad: Izdatel'stvo Akademii Nauk SSSR, 1950. (in Russian).

Petrukhin, Vladimir. “Ot tekh varyag prozvasya...” Rodina. No. 10 (1997), 4-16; (in Russian).

Petrukhin, Vladimir. Nachalo etnokul'turnoy istorii Rusi IX-XI vekov. Smolensk-Moskva, 1995. (in Russian).

Rybakov, Boris. Kivskaya Rus'i russkiye knyazhestva XII-XIII vv. Moskva: Nauka, 2013. (in Russian).

Rybakov, Boris. Mir istorii. Moskva: Molodaya gvardiya, 1984. (in Russian).

Rydzevskaya, Yelena. O roli varyagov v Drevney Rusi. Drevnyaya Rus'i Skandinaviya v IX$X I V v v$. Moskva: Nauka, 1978. (in Russian).

Svennung J. Zur Geschichte des goticismus. Stokholm: Almgvist och Wiksell, 1967. (in German)

Sinopsis. SPb.: Imperatorskaya Akademíya nauk, 1762. (in Russian).

Stang. Khokun. Naimenovaniye Rusi (gerul'skaya versiya). SPb.: Yevraziya, 2000. (in Russian).

Soyyer, Piter. Epokha vikingov. Per. s ang. A. P. Sanina. SPb.: Yevraziya, 2006. (in Russian).

Solovyov, Sergey. "Avgust-Lyudvig Shletser" Sobraniye sochiyeniy S. M. Solovyova. SPb.: Izdaniye Tovarishchestva Obshchestvennoy Pol'zy, 1901. (in Russian).

Tatishchev, Vasiliy. Istoriya Rossiyskaya s samikh drevneyshikh vremen. T.1. MoskvaLeningrad: Nauka, 1962.

Tolochko, Petro. Kyivs 'ka Rus'. Kyiv: Abris, 1996. (in Russian).

Thunmann J. Untersuchungen über die Geschichte der ostlichen europäischen Volker. Teil 1. Leipzig: 1774. (in Russian). (in German)

Fomin, V'yacheslav. Varyagi i varyazhskaya Rus'. K itogam diskussii po varyazhskomu voprosu. Moskva: Russkaya panorama. 2005. (in Russian).

Fomin, Vyacheslav. Nachal'naya istoriya Rusi. Moskva: Russkaya panorama, 2008. (in Russian).

Kherrman, Yoakhim. Slavyane i skandinavy v ranney istorii Baltiyskogo regiona. Per. s nem. Ye. A. Mel'nikovoy. Slavyane i skandinavy. Moskva: Progres, 1986. (in Russian).

Hubner, Jogan. Genealogische Tabellen, nebst denen dazu gehörigen genealogischen Fragen. T.1. Leipzig, 1725. (in German).

Ibn-Khordadbekh. Kniga putey i stran. Per. s arab. N. Velikhanovoy. Baku: ELM, 1986. (in Russian).

Shaskol's'kiy, Igor'. Vopros o proiskhozhdenii imeni “Rus"” v sovremennoy burzhuaznoy nauke. Kritika noveyshey burzhuaznoy istoriografii. Lenigrad: Nauka, 1967. (in Russian).

Shakhmatov, Aleksey. Skazaniye o prizvanii varyagov. Sankt-Peterburg: Tipografiya Imperatorskoy Akademii nauk, 1904. (in Russian).

Shletser, Avgust-Lyudvig. Nestor. CH. II. Per. s nem. D. Yazykova. SPb.: Imperatorskaya tipografiya, 1816. (in Russian).

Shchodra, Ol'ga. "Koly i de vynykla Rus': problemy pochatkovogo etapu formuvannia ukrains'koi derzhavnosti”. Visnyk NTSH. 58. (Osin'-zyma 2017): 31-37. (in Ukrainian).

Shchodra, Ol'ga. 'Epokha vikingiv u Skhidniy Evropi: slov'ians'ko-skandinavs'kí zviazky v period formuvannia rannikh slov'ians'kikh derzhav" Problemy slov'ianoznavstva. (2017). Vyp. 66, 9-27. (in Ukrainian).

Yamanov, Vladimir. Rorik Yutlands'kiy i letopisnyi Ryurik. Voprosy istorii. 4 (2002), 127-137. (in Russian). 
ISSN 2078-6077. Наукові зошити історичного факультету Львівського університету. 2018-2019. Випуск 19-20. Proceedings of History Faculty of Lviv University. 2018-2019. Issue 19-20.

Yanin, Valentin Srednevekovyy. Novgorod. Ocherki arkheologi i istorii. Moskva: Nauka, 2004. (in Russian).

Yansson, Ingmar Skandinavskiye nakhodki IX-Xvv. s Ryurikovovo gorodishcha. Velikiy Novgorod v istorii srednevekovoy Yevropy. (Moskva: Russkiye slovari, 1999), 35-39. (in Russian) 